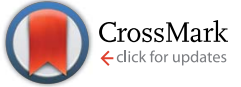

Cite this: RSC Adv., 2015, 5, 72900
Received 3rd June 2015

Accepted 11th August 2015

DOI: $10.1039 / \mathrm{c} 5 \mathrm{ra10538b}$

www.rsc.org/advances

\section{Porphyrin containing lipophilic amide groups as a photosensitizer for dye-sensitized solar cells $\dagger$}

\author{
J. Gasiorowski, ${ }^{a}$ N. Pootrakulchote, ${ }^{b}$ C. Reanprayoon, ${ }^{c}$ K. Jaisabuy, ${ }^{d}$ \\ P. Vanalabhpatana, ${ }^{d}$ N. S. Sariciftci ${ }^{a}$ and P. Thamyongkit ${ }^{\star d}$
}

In this study, synthesis and investigation of a novel zinc-porphyrin derivative bearing $\mathrm{C}_{24}$-containing amide groups for potential use in dye-sensitized solar cells (DSSCs) are presented. According to absorption spectra and electrochemical data, the target porphyrin has appropriate highest occupied molecular orbital (HOMO) and lowest unoccupied molecular orbital (LUMO) energy levels. The device studies revealed that the DSSCS based on the target porphyrin exhibited higher light harvesting efficiency in the Q-band region and an increased photocurrent, compared to the DSSCs based on a benchmark derivative bearing no alkyl amide groups on the meso-phenyl substituents. The optimum DSSC based on the target porphyrin gave a short-circuit photocurrent density $\left(J_{\mathrm{sc}}\right)$, an open-circuit voltage $\left(V_{\mathrm{oc}}\right)$ and a fill factor (FF) of $5.6 \mathrm{~mA} \mathrm{~cm}^{-2}, 0.7 \mathrm{~V}$ and 0.78 , respectively, with an overall power conversion efficiency (PCE) of $3.1 \%$.

\section{Introduction}

With their large molar absorption coefficients, and amenability to structural modifications for tuning of the electrochemical and photophysical properties, porphyrin derivatives have attracted interest in the field of organic optoelectronics. ${ }^{1}$ Since the great success in developing a porphyrin-based dyesensitized solar cell (DSSC) with a power conversion efficiency (PCE) of $12.3 \%$ in $2011,^{2}$ intensive efforts have been made towards the design and development of novel porphyrins to enhance the cell efficiency. In the operation of DSSCs, one of the critically undesirable pathways is charge recombination between the photo-injected electron at $\mathrm{TiO}_{2}$ and the oxidized dye and/or electrolyte. Ballester and Palomares et al. reported the suppression of the recombination between the photoinjected electron at $\mathrm{TiO}_{2}$ and the electrolyte in the DSSCs by using a porphyrin dye bearing $\mathrm{C}_{5}$ alkyl groups on the mesophenyl substituents. ${ }^{3}$ Moreover, the sizable linear alkyl chains were reported to form a hydrophobic layer covering the dye layer, resulting in a higher stability of the DSSCs. ${ }^{4}$ The alkyl

${ }^{a}$ Linz Institute for Organic Solar Cells (LIOS), Institute of Physical Chemistry, Johannes Kepler University of Linz, Linz 4040, Austria

${ }^{b}$ Department of Chemical Technology, Faculty of Science, Chulalongkorn University, Bangkok 10330, Thailand

'Program in Petrochemistry and Polymer Science, Faculty of Science, Chulalongkorn University, Bangkok 10330, Thailand

${ }^{d}$ Department of Chemistry, Faculty of Science, Chulalongkorn University, Bangkok 10330, Thailand. E-mail: patchanita.v@chula.ac.th; Fax: +66-2-254-1309; Tel: +662-218-7587

$\dagger$ Electronic supplementary information (ESI) available: Spectral data, including ${ }^{1} \mathrm{H}$-NMR spectrum, ${ }^{13} \mathrm{C}-\mathrm{NMR}$ spectrum and mass spectra for new compounds. See DOI: $10.1039 / \mathrm{c} 5 \mathrm{ra} 10538 \mathrm{~b}$ chains also have a self-assembly property that can give a wellorganized surface coverage of the dyes on the $\mathrm{TiO}_{2}$ films and efficient electron injection. ${ }^{5}$ In this work, we aim to synthesize and investigate a novel zinc-porphyrin bearing three $\mathrm{C}_{24}$-containing amide groups, and a carboxyl group at the para positions of the meso-phenyl substituents for its potential use in DSSCs. The $\mathrm{C}_{24}$ alkyl chain was used in this study as a representative of the long linear alkyl chains. An amide group was chosen to be a linker between the porphyrin macrocycle and the $\mathrm{C}_{24}$ alkyl meso-substituents because it is known as a robust functional group that can be readily formed. Furthermore, the amide group was demonstrated to promote self assembly in the dye layers of the organic solar cells by hydrogen bonding. ${ }^{6}$ The photophysical and electrochemical properties of the target molecule, and the effect of the $\mathrm{C}_{24}$-containing amide groups on the DSSC performance will give useful guidelines for the introduction of long alkyl chains into porphyrinic photosensitizing systems in DSSCs.

\section{Experimental section}

\section{Materials and methods}

All chemicals were analytical grade, purchased from commercial suppliers and used as received without further purification. ${ }^{1} \mathrm{H}$-Nuclear Magnetic Resonance (NMR) and ${ }^{13} \mathrm{C}-\mathrm{NMR}$ spectra were obtained in deuterated chloroform $\left(\mathrm{CDCl}_{3}\right)$ using an NMR spectrometer operated at 400 megahertz $(\mathrm{MHz})$ for ${ }^{1} \mathrm{H}$ and 100 $\mathrm{MHz}$ for ${ }^{13} \mathrm{C}$ nuclei. Chemical shifts $(\delta)$ are reported in parts per million (ppm) relative to the residual $\mathrm{CHCl}_{3}$ peak (7.26 ppm for ${ }^{1} \mathrm{H}-\mathrm{NMR}$ and $77.0 \mathrm{ppm}$ for $\left.{ }^{13} \mathrm{C}-\mathrm{NMR}\right)$. Coupling constants $(J)$ are reported in Hz. Mass spectra were obtained by matrix-assisted laser desorption ionization mass spectrometry (MALDI-MS) 
using dithranol as a matrix. Absorption and emission spectra of the solutions were measured in toluene at room temperature and an absorption extinction coefficient $(\varepsilon)$ was reported in $\mathrm{M}^{-1} \mathrm{~cm}^{-1}$. The absorption of the porphyrin film on $\mathrm{TiO}_{2}$ was recorded at room temperature by using the same $\mathrm{TiO}_{2}$ film as a blank.

\section{Non-commercial compound}

Porphyrin $\mathbf{4}$ was prepared following a literature procedure. ${ }^{7}$

\section{Synthesis of tetracosan-1-amine (3)}

Following a published method ${ }^{8}$ with a modified reaction time and work-up procedure, a mixture of lignoceric acid $(1,1.002 \mathrm{~g}$, $2.718 \mathrm{mmol})$ and thionyl chloride $(1.800 \mathrm{~g}, 15.13 \mathrm{mmol})$ in tetrahydrofuran (THF, $4 \mathrm{~mL}$ ) was refluxed for $1 \mathrm{~h}$. The remaining thionyl chloride was removed under reduced pressure to obtain an orange brown oil containing tetracosanoyl chloride, which was treated with a cold aqueous ammonia solution $(25 \%$ $\mathrm{w} / \mathrm{w}, 20 \mathrm{~mL}$ ) at room temperature. After $3 \mathrm{~h}$, the mixture was extracted with $\mathrm{CH}_{2} \mathrm{Cl}_{2}(3 \times 50 \mathrm{~mL})$. The organic phase was collected and dried over anhydrous magnesium sulfate. After the removal of solvent under reduced pressure, the resulting yellow crude product was treated with hexane $(30 \mathrm{~mL})$. The mixture was then sonicated for $10 \mathrm{~min}$ and placed in a refrigerator $\left(4^{\circ} \mathrm{C}\right)$ overnight for precipitation. The resulting precipitate was filtered and washed with cold hexane and dried under vacuum to obtain tetracosanamide (2) as a colorless solid (0.802 $\mathrm{g}, 80 \%) .{ }^{1} \mathrm{H}-\mathrm{NMR} \delta 0.87(\mathrm{t}, J=6.8 \mathrm{~Hz}, 3 \mathrm{H}), 1.03-1.45(\mathrm{~m}, 30 \mathrm{H})$, $1.51-1.67(\mathrm{~m}, 4 \mathrm{H}), 1.72-1.91(\mathrm{~m}, 4 \mathrm{H}), 2.29(\mathrm{t}, J=8.0 \mathrm{~Hz}, 2 \mathrm{H})$, $3.53-3.60(\mathrm{t}, J=6.4 \mathrm{~Hz}, 2 \mathrm{H}), 4.05-4.12(\mathrm{t}, J=6.4 \mathrm{~Hz}, 2 \mathrm{H}) ;{ }^{13} \mathrm{C}-$ NMR $\delta$ 14.1, 22.7, 25.0, 26.1, 29.15, 29.18, 29.3, 29.4, 29.5, 29.6, 29.65, 29.69, 31.9, 34.3, 44.4, 63.3, 173.9; MALDI-TOF-MS $\mathrm{m} / \mathrm{z}$ obsd $367.934\left[\mathrm{M}^{+}\right]$, calcd $367.652\left(\mathrm{M}=\mathrm{C}_{24} \mathrm{H}_{49} \mathrm{NO}\right)$.

A solution of compound $2(0.802 \mathrm{~g}, 2.18 \mathrm{mmol})$ in diethyl ether $(20 \mathrm{~mL})$ was treated with $\mathrm{LiAlH}_{4}(0.805 \mathrm{~g}, 21.2 \mathrm{mmol})$ at $0{ }^{\circ} \mathrm{C}$ and the reaction was continued at room temperature for 17 h. After that, the reaction was quenched by adding water $(1.00$ $\mathrm{mL}), 15 \% \mathrm{NaOH}(1.00 \mathrm{~mL})$ and then water $(3.00 \mathrm{~mL})$. The mixture was filtered and the resulting filtrate was concentrated under reduced pressure, leading to tetracosan-1-amine (3) as a colorless solid $(0.515 \mathrm{~g}, 67 \%) .{ }^{1} \mathrm{H}-\mathrm{NMR} \delta 0.82-0.97(\mathrm{~m}, 11 \mathrm{H})$, 1.00-1.49 (m, 18H), 1.49-1.63 (m, 8H), 1.63-1.77 (m, 2H), 1.77$1.96(\mathrm{~m}, 2 \mathrm{H}), 2.67(\mathrm{t}, J=6.8 \mathrm{~Hz}, 2 \mathrm{H}), 3.63(\mathrm{~m}, 8 \mathrm{H}) ;{ }^{13} \mathrm{C}-\mathrm{NMR} \delta$ 14.1, 22.7, 25.8, 26.9, 29.35, 29.44, 29.5, 29.6, 29.7, 31.9, 32.8, 33.8, 42.2, 63.0; MALDI-TOF-MS $m / z$ obsd $353.835\left[\mathrm{M}^{+}\right]$, calcd $353.668\left(\mathrm{M}=\mathrm{C}_{24} \mathrm{H}_{51} \mathrm{~N}\right)$.

\section{Synthesis of Zn-5}

Following a previously reported procedure ${ }^{9}$ with modified stoichiometry, a solution of porphyrin $4^{7}(0.149 \mathrm{~g}, 0.188 \mathrm{mmol})$ in THF $(10 \mathrm{~mL})$ was treated with $N$-hydroxysuccinimide (NHS, $0.217 \mathrm{~g}, \quad 1.88 \mathrm{mmol}, \quad 10$ equiv.) and 1-ethyl-3-(3dimethylaminopropyl)carbodiimide hydrochloride $(\mathrm{EDC} \cdot \mathrm{HCl}$, $0.432 \mathrm{~g}, 2.26 \mathrm{mmol}, 12$ equiv.). The reaction mixture was stirred at refluxing temperature for $2 \mathrm{~d}$ and then the solvent was removed under reduced pressure. The crude mixture was redissolved in THF $(10 \mathrm{~mL})$ and the resulting solution was treated with compound $3(0.815 \mathrm{~g}, 2.30 \mathrm{mmol}, 12$ equiv. $)$ and triethylamine (TEA, $5 \mathrm{~mL}$ ). The reaction mixture was stirred at refluxing temperature for $1 \mathrm{~d}$ and then the solvent was removed under reduce pressure. Column chromatography [silica, $\mathrm{CH}_{2} \mathrm{Cl}_{2}: \mathrm{EtOH}:$ TEA $\left.(96: 3: 1)\right]$ afforded a crude product containing compound 5: MALDI-TOF-MS $m / z$ obsd $1800.122\left[\mathrm{M}^{+}\right]$, calcd $1797.733\left(\mathrm{M}=\mathrm{C}_{120} \mathrm{H}_{177} \mathrm{~N}_{7} \mathrm{O}_{5}\right)$. Following a previously published procedure, ${ }^{10}$ a solution of compound $\mathbf{5}$ in chloroform $(3 \mathrm{~mL})$ was reacted with a solution of zinc acetate dihydrate $(0.045 \mathrm{~g}, 0.206 \mathrm{mmol})$ in methanol $(1 \mathrm{~mL})$ at room temperature for $3 \mathrm{~h}$. After that, the resulting mixture was extracted by $\mathrm{CH}_{2} \mathrm{Cl}_{2}$ and $\mathrm{H}_{2} \mathrm{O}$. The organic phase was dried over anhydrous magnesium sulfate and concentrated under reduced pressure. The resulting solid was washed with hexane and then methanol to afford compound Zn-5 as a purple solid $(0.016 \mathrm{~g}, 5 \%$ from compound 4). $\mathrm{Mp}>230{ }^{\circ} \mathrm{C}$ (from methanol); ${ }^{1} \mathrm{H}-\mathrm{NMR} \delta 0.81-$ $0.92(\mathrm{~m}, 12 \mathrm{H}), 1.15-1.59(\mathrm{~m}, 81 \mathrm{H}), 1.68-1.83(\mathrm{~m}, 6 \mathrm{H}), 1.85-2.60$ $(\mathrm{m}, 30 \mathrm{H}), 3.36-3.78(\mathrm{~m}, 18 \mathrm{H}), 6.43-6.51(\mathrm{~m}, 3 \mathrm{H}), 8.09-8.18$ $(\mathrm{m}, 6 \mathrm{H}), 8.20-8.30(\mathrm{~m}, 8 \mathrm{H}), 8.40-8.52(\mathrm{~m}, 2 \mathrm{H}), 8.74-8.87$ $(\mathrm{m}, 8 \mathrm{H}) ;{ }^{13} \mathrm{C}-\mathrm{NMR} \delta$ 8.0, 8.1, 8.6, 11.1, 12.0, 14.0, 19.1, 22.6, 23.8, 25.5, 27.1, 27.7, 28.3, 28.6, 28.8, 29.0, 29.2, 29.4, 29.6, 29.8, 31.8, $39.6,40.3,42.2,45.8,52.9,58.05,58.09,63.2,65.2,67.5,67.9$, $70.5,119.2,119.3,120.2,125.4,127.9,131.3,134.2,134.4,134.5$, 141.2, 144.6, 144.8, 144.9, 167.4, 170.9; MALDI-TOF-MS m/z obsd $1862.492\left[\mathrm{M}^{+}\right]$, calcd $1861.127\left(\mathrm{M}=\mathrm{ZnC}_{120} \mathrm{H}_{175} \mathrm{~N}_{7} \mathrm{O}_{5}\right) ; \lambda_{\text {abs }}$ (E) $426\left(3.2 \times 10^{5}\right), 556,597 ; \lambda_{\mathrm{em}}\left(\lambda_{\mathrm{ex}}=426 \mathrm{~nm}\right) 605,651 \mathrm{~nm}$.

\section{Electrochemical studies}

Cyclic voltammetric measurements were carried out with an Autolab PGSTAT101 potentiostat/galvanostat (Eco Chemie, the Netherlands) using a conventional three-electrode configuration. A water-jacketed glass cell was employed to control the reaction temperature. A glassy carbon electrode with a disk diameter of $3.0 \mathrm{~mm}$ was used as a working electrode. Before use, the electrode was polished with an aqueous suspension of alumina powder and rinsed thoroughly with deionized water. A platinum wire was applied as an auxiliary electrode. All potentials are quoted with respect to a silver/silver ion $\left(\mathrm{Ag} / \mathrm{Ag}^{+}\right)$ reference electrode in an acetonitrile solution; this electrode was externally calibrated with a ferrocene/ferrocenium ion $(\mathrm{Fc} /$ $\mathrm{Fc}^{+}$) redox couple and has a potential of $0.548 \mathrm{~V} v s$. a normal hydrogen electrode (NHE). ${ }^{11}$ Cyclic voltammograms were recorded at scan rates of $100-500 \mathrm{mV} \mathrm{s}^{-1}$ in freshly distilled and deoxygenated $\mathrm{CH}_{2} \mathrm{Cl}_{2}$ containing $0.10 \mathrm{M}$ tetrabutylammonium perchlorate (TBAP). A deaeration procedure was carried out with the aid of ultra-high purity (UHP) argon.

\section{Device fabrication and characterization}

A mesoscopic $\mathrm{TiO}_{2}$ film was composed of an $8 \mu \mathrm{m}$ thick transparent layer of $20 \mathrm{~nm}$ sized $\mathrm{TiO}_{2}$ anatase nanoparticles onto which a second $5 \mu \mathrm{m}$ thick scattering layer of $400 \mathrm{~nm}$ sized $\mathrm{TiO}_{2}$ was superimposed. The detailed methods for $\mathrm{TiO}_{2}$ film preparation, device fabrication, and photocurrent-voltage measurements can be found in an earlier report. ${ }^{12}$ The double layer films were heated to $500{ }^{\circ} \mathrm{C}$ and sintered for $30 \mathrm{~min}$. After cooling 
down to $80{ }^{\circ} \mathrm{C}$, the films were immersed into the dye solution $(300 \mu \mathrm{M})$ in a mixture of THF and ethyl alcohol $(\mathrm{v} / \mathrm{v}, 1 / 4)$ for $16 \mathrm{~h}$. The stained photoanode was fabricated with the platinized counter electrode using a $25 \mu \mathrm{m}$ thick Surlyn film (Dupont, USA) and sealed by a hot-press machine. In this study, an acetonitrilebased electrolyte containing $1.0 \mathrm{M}$ 1,3-dimethylimidazolium iodide (DMII), 0.1 M LiI, $30 \mathrm{mM} \mathrm{I}_{2}, 0.5 \mathrm{M}$ tert-butylpyridine ( $t$ $\mathrm{BP}$ ), and $0.1 \mathrm{M}$ guanidiniumthiocyanate (GNCS) in a mixed solvent of acetonitrile and valeronitrile (v/v, 85/15) was used to fill the internal gap between the two glasses.

To characterize the solar cells, a $450 \mathrm{~W}$ xenon light source (Oriel, USA) was used. The current-voltage characteristics were obtained by applying external potential bias to the cell and measuring the generated photocurrent with a Keithley model 2400 digital source meter (Keithley, USA). The devices were masked to attain an illuminated active area of $0.159 \mathrm{~cm}^{2}$. Loss of light reflection from the photoanode glass was reduced by applying a self-adhesive fluorinated polymer anti-reflecting film (ARKTOP, Asahi glass). Up to four devices were fabricated for each experimental variable change to give accurate statistics. A modulated light intensity data acquisition system was used to control the incident photon-to-current conversion efficiency (IPCE) measurement. The modulation frequency was about 1 Hz. Light from a $300 \mathrm{~W}$ xenon lamp (ILC Technology, USA) was focused through a computer controlled Gemini-180 double monochromator (Jobin Yvon Ltd, UK) onto the photovoltaic cell. White light bias was used to bring the total light intensity on the device closer to the operating conditions.

Photovoltage transients were detected by using a pump pulse generated by four red light emitting diodes controlled by a fast solid-state switch with a white light bias. The pulse of the red light with a width of $50 \mathrm{~ms}$ was incident on the photoanode side of the cell, and its intensity was controlled to keep a suitably low level for the generation of the exponential voltage decay where the charge recombination rate constants were obtained directly from the exponential decay rate. ${ }^{13}$ The white bias light, also incident on the same side of the device, was supplied by white diodes. The photo-induced charge density as function of the white light bias intensity was obtained by charge extraction measurement where the stored charges under open circuit conditions were extracted by placing the cell under short circuit conditions.

\section{Results and discussion}

\section{Synthesis}

The synthesis started with a reaction between lignoceric acid (1) and thionyl chloride to obtain the corresponding acid chloride, which was reacted further with a $25 \% \mathrm{NH}_{4} \mathrm{OH}$ solution, leading

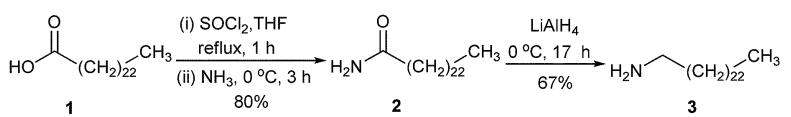

Scheme 1 Synthesis of amine precursor 3. to compound 2 in $80 \%$ yield (Scheme 1 ). After that, compound 2 was reduced by $\mathrm{LiAlH}_{4}$ to afford compound 3 in $67 \%$ yield.

The preparation of the target compound relies on a threestep procedure recently published by our group. ${ }^{9}$ Compound $\mathbf{4}^{7}$ was subjected to a reaction with $\mathrm{NHS}$ and $\mathrm{EDC} \cdot \mathrm{HCl}$, followed by a condensation of the resulting air-sensitive succinimidyl ester with an excess amount of amine $\mathbf{3}$ to give freebase porphyrin 5 (Scheme 2). The yields from these two steps were low mainly due to the incompletion of the reaction at three reaction sites as desired, despite the use of a large excess of $\mathrm{NHS}, \mathrm{EDC} \cdot \mathrm{HCl}$ and amine 3, and a long reaction time. Moreover, attempts to separate compound $\mathbf{5}$ from other possible condensed by-products and impurities failed give pure compound 5. Therefore, the resulting crude product containing 5 was directly metallated by $\mathrm{Zn}(\mathrm{OAc}) \cdot 2 \mathrm{H}_{2} \mathrm{O}$. After the lengthy chromatographic separation, Zn-5 was obtained in $5 \%$ overall yield. In the mass spectrum, the molecular ion peak of $\mathbf{Z n - 5}$ was observed at $m / z$ 1862.492, confirming the formation of $\mathbf{Z n - 5}$. The solubility of Zn-5 in common organic solvents, e.g. $\mathrm{CH}_{2} \mathrm{Cl}_{2}$, $\mathrm{CHCl}_{3}$, and THF, was found to be approximately $10 \mathrm{mg} \mathrm{mL} \mathrm{mL}^{-1}$, which is sufficient for a routine wet process in the DSSC fabrication.

\section{Photophysical and electrochemical properties}

As shown in Fig. 1, an absorption spectrum of the Zn-5 solution in toluene exhibited a characteristic pattern of a Zn-porphyrin

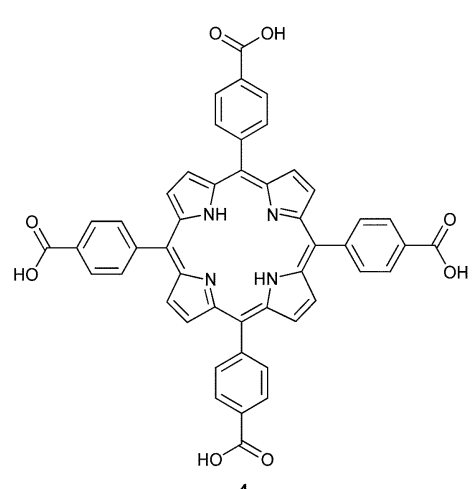

$$
\text { 5\% } \mid \begin{aligned}
& \text { (i) } \mathrm{NHS}, \mathrm{EDC} \cdot \mathrm{HCl}, \mathrm{THF} \\
& \text { reflux, 2d } \\
& \text { (ii) } \mathrm{CH}_{3}\left(\mathrm{CH}_{2}\right)_{23} \mathrm{NH}_{2} \text { (3) } \\
& \mathrm{TEA}, \mathrm{THF}, \text { reflux, } 1 \mathrm{~d} \\
& \text { (iii) } \mathrm{Zn}(\mathrm{OAC})_{2} \cdot 2 \mathrm{H}_{2} \mathrm{O} \\
& \mathrm{MeOH} / \mathrm{CHCl}_{3}, \mathrm{rt}, 3 \mathrm{~h}
\end{aligned}
$$

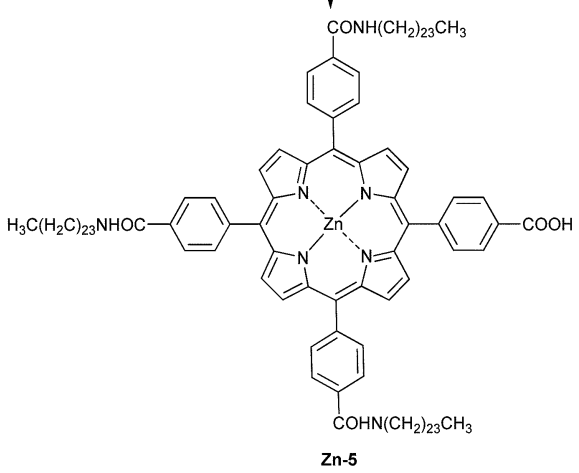

Scheme 2 Synthesis of the target compound. 


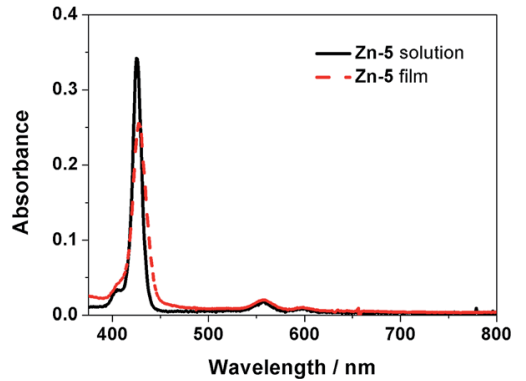

Fig. 1 Absorption spectra of the $\mathbf{Z n - 5}$ solution in toluene (black solid line) and the $\mathrm{Zn}-5$ film on $\mathrm{TiO}_{2}$ (red dashed line).

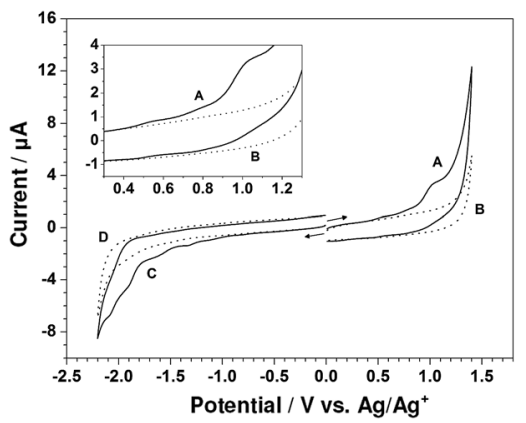

Fig. 2 Cyclic voltammograms recorded with the glassy carbon electrode (area $=0.071 \mathrm{~cm}^{2}$ ) at $100 \mathrm{mV} \mathrm{s}^{-1}$ in $\mathrm{CH}_{2} \mathrm{Cl}_{2}$ containing $0.10 \mathrm{M}$ TBAP in the presence of $1.00 \mathrm{mM} \mathrm{Zn-5}$ (curves $\mathrm{A}$ and $\mathrm{C}$ ) and $\mathrm{CH}_{2} \mathrm{Cl}_{2}$ containing only $0.10 \mathrm{M}$ TBAP (curves $B$ and $D$ ). Curves $A$ and $B$ were initially scanned in the positive direction; while curves ( $C$ and $D)$ were initially scanned in the negative direction. Inset is an expansion of the region between 0.30 and $1.30 \mathrm{~V}$.

having an intense B-band at $426 \mathrm{~nm}$, and Q-bands at 556 and 597 nm (black solid line). The absorption pattern of a Zn-5 film on $\mathrm{TiO}_{2}$ was very similar with slightly broader bands than those of the Zn-5 solution, most likely due to the aggregation of the porphyrin macrocycle (red dashed line). This observation indicated that the $\mathrm{C}_{24}$-containing amide groups on the meso-phenyl substituents of the porphyrin ring did not significantly affect the photophysical properties of $\mathbf{Z n - 5}$ in terms of absorption as a function of the wavelength of incident light.

Shown in Fig. 2 are cyclic voltammograms obtained with a glassy carbon electrode at the scan rate of $100 \mathrm{mV} \mathrm{s}^{-1}$ in the potential range of -2.20 to $1.40 \mathrm{~V}$ for $\mathrm{CH}_{2} \mathrm{Cl}_{2}$ containing $0.10 \mathrm{M}$ TBAP in the presence and absence of $1.00 \mathrm{mM} \mathrm{Zn-5}$. Curves B and $\mathrm{D}$, recorded as background cyclic voltammograms, exhibit no significant peaks of the TBAP- $\mathrm{CH}_{2} \mathrm{Cl}_{2}$ electrolyte solution. In the positive potential region, a cyclic voltammogram for the oxidation of Zn-5 (curve A) reveals some electrochemical features of Zn-5. As can be seen in the inset of Fig. 2 presenting the magnified voltammograms from 0.30 to $1.30 \mathrm{~V}$, three successive quasireversible redox couples exist. The anodic peak potentials are approximately at $0.54,0.79$ and $1.01 \mathrm{~V}$, while the corresponding cathodic peak potentials are at $0.46,0.71$ and $0.92 \mathrm{~V}$, respectively. When the potential was negatively scanned from $0 \mathrm{~V}$ to $-2.20 \mathrm{~V}$ (curve $\mathrm{C}$ ), the electro-reduction of $\mathbf{Z n - 5}$ gave
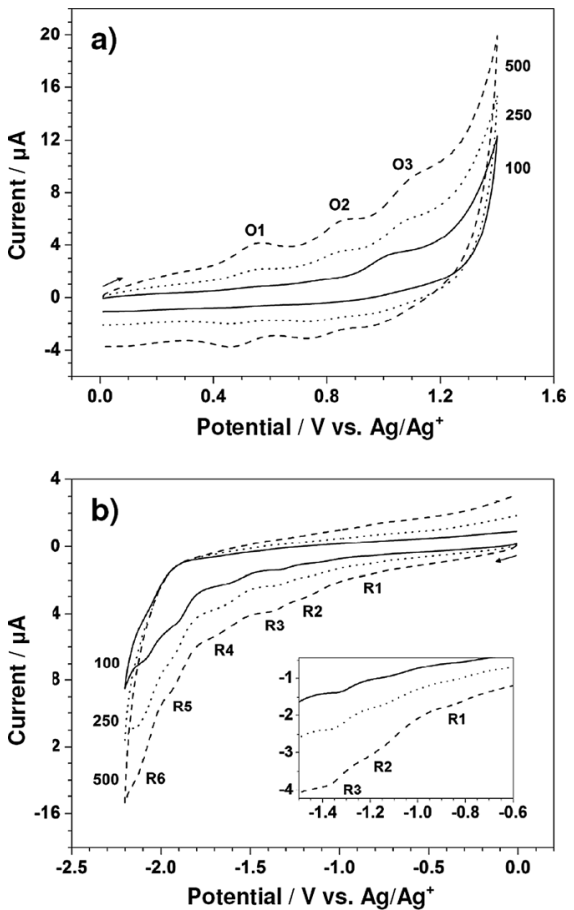

Fig. 3 Cyclic voltammograms recorded with the glassy carbon electrode (area $=0.071 \mathrm{~cm}^{2}$ ) from (a) 0 to 1.40 to $0 \mathrm{~V}$ and (b) 0 to -2.20 to $0 \mathrm{~V}$ in $\mathrm{CH}_{2} \mathrm{Cl}_{2}$ containing 0.10 M TBAP and $1.00 \mathrm{mM} \mathrm{Zn-5}$ at 100 (solid line), 250 (dotted line), and 500 (dashed line) $\mathrm{mV} \mathrm{s}^{-1}$. Inset is an expansion of the region between -0.60 and $-1.50 \mathrm{~V}$.

relatively small and poorly defined irreversible cathodic peaks at approximately $-0.81,-1.13,-1.33,-1.61,-1.91$ and -2.08 $\mathrm{V}$, implying multi-step ligand-centered reduction of the porphyrinic units and the conjugated system of the compound. ${ }^{\mathbf{1 4}}$

To enhance the current size and thoroughly observe the electrochemical behavior of Zn-5, its cyclic voltammograms were further collected at the scan rates of 250 and $500 \mathrm{mV} \mathrm{s}^{-1}$. Fig. 3a and b display cyclic voltammograms of $1.00 \mathrm{mM}$ Zn-5 solution initially scanned in anodic and cathodic directions, respectively, at 100, 250 and $500 \mathrm{mV} \mathrm{s}^{-1}$. All peaks appearing in the cyclic voltammograms recorded at $100 \mathrm{mV} \mathrm{s}^{-1}$ also exist in those collected at the higher scan rates with larger magnitudes and slight shifts in position. Table 1 summarizes the peak potentials $\left(E_{\mathrm{p}}\right)$ for the oxidation and reduction of $\mathbf{Z n - 5}$ at these three scan rates. Due to the unresolved nature of some peaks especially those of the reduction processes, each cyclic voltammetric peak was treated as a parabolic curve of which the vertex represents the peak potential. Using scientific graphing and data analysis software, two tangent lines from both sides were drawn to achieve the intercept which is connected with the vertex via a straight line perpendicular to the parabola base. ${ }^{15}$ To achieve accurate peak potential values, at least three measurements were made at all positions and the relative standard deviations of the obtained potentials are less than $0.35 \%$.

For the oxidation of $\mathbf{Z n - 5}$, the differences between the anodic and cathodic peak potentials $\left(\Delta E_{\mathrm{p}}\right)$ of the three redox couples are approximately $80-110 \mathrm{mV}$. Since an electron transfer in high-resistance organic media always gives a $\Delta E_{\mathrm{p}}$ value larger 
Table 1 Peak potential $\left(E_{\mathrm{p}}\right)$ values for the cyclic voltammograms ${ }^{a}$ of $\mathrm{Zn}-5$

\begin{tabular}{|c|c|c|c|c|c|c|c|c|c|c|c|c|}
\hline \multirow[b]{3}{*}{ Scan rate $/ \mathrm{mV} \mathrm{s}^{-1}$} & \multicolumn{6}{|c|}{ Oxidation (from 0 to 1.40 to $0 \mathrm{~V}$ ) } & \multicolumn{6}{|c|}{ Reduction (from 0 to -2.20 to $0 \mathrm{~V}$ ) } \\
\hline & \multicolumn{3}{|c|}{$\begin{array}{l}E_{\mathrm{pa}} \text { in the forward scan/ } \\
\mathrm{V}\end{array}$} & \multicolumn{3}{|c|}{$\begin{array}{l}E_{\mathrm{pc}} \text { in the backward } \\
\text { scan/V }\end{array}$} & \multicolumn{6}{|c|}{$E_{\mathrm{pc}}$ in the forward scan/V } \\
\hline & O1 & $\mathrm{O} 2$ & $\mathrm{O} 3$ & O1 & $\mathrm{O} 2$ & $\mathrm{O} 3$ & R1 & $\mathrm{R} 2$ & $\mathrm{R} 3$ & $\mathrm{R} 4$ & R5 & R6 \\
\hline 100 & 0.54 & 0.79 & 1.01 & 0.46 & 0.71 & 0.92 & -0.81 & -1.13 & -1.33 & -1.61 & -1.91 & -2.08 \\
\hline
\end{tabular}

${ }^{a} E_{\mathrm{pa}}=$ anodic peak potential; and $E_{\mathrm{pc}}=$ cathodic peak potential. Each entry represents the average peak potential value achieved from at least three measurements. The potential is quoted with respect to the $\mathrm{Ag} / \mathrm{Ag}^{+}$reference electrode and externally calibrated with the $\mathrm{Fc} / \mathrm{Fc}^{+}$redox couple having a potential of $0.548 \mathrm{~V} v s$. NHE. ${ }^{11}$

Table 2 Half-peak potential $\left(E_{1 / 2}\right)$ values for the oxidation ${ }^{a}$ of $\mathbf{Z n - 5}$

\begin{tabular}{llll}
\hline & \multicolumn{3}{l}{ Half-peak potential $\left(E_{1 / 2}\right) / \mathrm{V}$} \\
\cline { 2 - 4 } Scan rate/mV s & & \\
\hline & $\mathrm{O} 1$ & $\mathrm{O} 2$ & $\mathrm{O} 3$ \\
\hline 00 & 0.50 & 0.75 & 0.97 \\
250 & 0.51 & 0.79 & 1.02 \\
500 & 0.51 & 0.79 & 1.02
\end{tabular}

${ }^{a} E_{1 / 2}=\left(E_{\mathrm{pa}}+E_{\mathrm{pc}}\right) / 2$, when $E_{\mathrm{pa}}=$ anodic peak potential and $E_{\mathrm{pc}}=$ cathodic peak potential. ${ }^{16}$ The potential is quoted with respect to the $\mathrm{Ag} / \mathrm{Ag}^{+}$reference electrode and externally calibrated with the $\mathrm{Fc} / \mathrm{Fc}^{+}$ redox couple having a potential of $0.548 \mathrm{~V} v s$. NHE. ${ }^{11}$

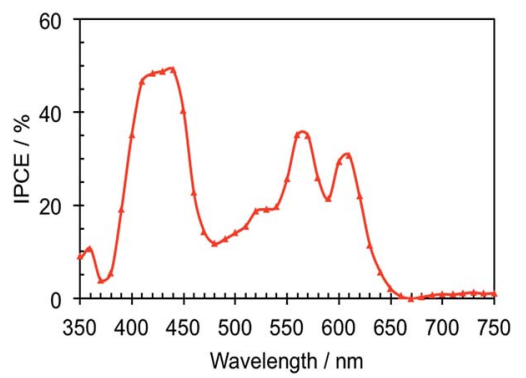

Fig. 4 IPCE spectrum of the Zn-5-based DSSCs.

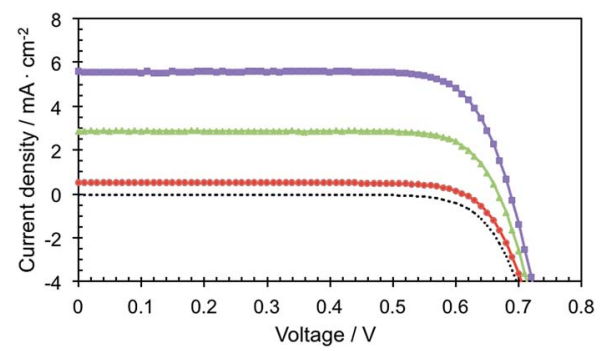

Fig. 5 Photocurrent density-voltage curves of the Zn-5-based DSSCS.

than the theoretical value of $59 / n \mathrm{mV}^{16}$ and the $\Delta E_{\mathrm{p}}$ for the oneelectron, reversible $\mathrm{Fc} / \mathrm{Fc}^{+}$couple in the $0.10 \mathrm{M}$ TBAP- $\mathrm{CH}_{2} \mathrm{Cl}_{2}$ solution has a value of nearly $120 \mathrm{mV}$ (data not shown), each
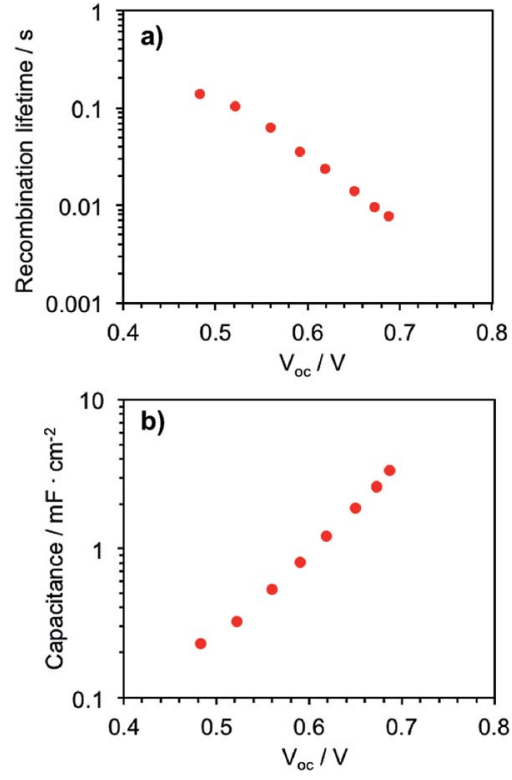

Fig. 6 (a) Electron recombination lifetime and (b) chemical capacitance plotted as a function of open circuit voltage in the $\mathbf{Z n - 5}$-based DSSCs, derived from photovoltage transients at the various white light bias intensities.

oxidation of $\mathbf{Z n - 5}$ in $\mathrm{CH}_{2} \mathrm{Cl}_{2}$ possibly involves one electron. In addition, it is worthwhile to consider the effect of the scan rate on peak current even though not all of the peak currents could be determined due to size limitations. For the third oxidation (O3), the anodic peak currents at 100, 250 and $500 \mathrm{mV} \mathrm{s}^{-1}$ are $1.41,2.05$ and $3.01 \mu \mathrm{A}$, respectively. A plot of these anodic peak currents $v s$. the square root of scan rates demonstrates linear behavior (not shown), elucidating the diffusion-controlled oxidation process of $\mathbf{Z n - 5}$.

Using the data in Table 1, a half-peak potential $\left(E_{1 / 2}\right)$ for the oxidation of Zn-5 in $\mathrm{CH}_{2} \mathrm{Cl}_{2}$ containing $0.10 \mathrm{M}$ TBAP can be calculated. Table 2 displays $E_{1 / 2}$ values of all three oxidations. Following the previous studies, ${ }^{17}$ the data from cyclic voltammetry and absorption spectroscopy can be used to estimate the highest occupied molecular orbital (HOMO) and lowest unoccupied molecular orbital (LUMO) energy levels of the dyes. The $E_{1 / 2}$ value of the first oxidation $\left(E_{1 / 2}(\mathrm{ox} 1)\right)$ can represent the 
HOMO energy level of a dye, while the LUMO energy level can be calculated from an excited state oxidation potential $\left(E_{0-0}^{*}\right)$ by the following equation:

$$
E_{0-0}^{*}=E_{1 / 2}(\mathrm{ox} 1)-E_{0-0},
$$

where $E_{0-0}$ is the absorption onset of the dye that represents its energy gap. The results indicated that the HOMO energy level and the energy gap of $\mathbf{Z n}-5$ were $0.50 \mathrm{~V}$ and $2.03 \mathrm{~V}$, respectively. Therefore, its LUMO energy level was calculated to be $-1.53 \mathrm{~V}$. With the LUMO energy level being more negative than the conduction band of $\mathrm{TiO}_{2}\left(-0.50 \mathrm{~V}\right.$ vs. $\left.\mathrm{NHE}^{17}\right)$, the electron injection of the excited dye to $\mathrm{TiO}_{2}$ surface should be thermodynamically possible in the $\mathbf{Z n}$-5-based DSSCs. At the same time, the more positive energy level of its HOMO compared with the oxidation potential of an iodide ion/triiodide ion $\left(\mathrm{I}^{-} / \mathrm{I}_{3}{ }^{-}\right)$redox couple $\left(0.40 \mathrm{~V} v s . \mathrm{NHE}^{17}\right)$ suggests that the dye regeneration by the $\mathrm{I}^{-} / \mathrm{I}_{3}{ }^{-}$electrolyte should be also favorable in the devices.

\section{Photovoltaic characteristics}

The photovoltaic performance of Zn-5-based DSSCs, i.e. the photocurrent density-voltage $(J-V)$ curve, and IPCE were investigated in the test devices using a standard double layer $\mathrm{TiO}_{2}$ film $(8+5 \mu \mathrm{m})$ and a volatile acetonitrile-based electrolyte. The detailed composition is described in the Device fabrication section. The IPCE of the Zn-5-based device in Fig. 4 shows the peak values of $49.1 \%, 35.2 \%$ and $30.7 \%$ at $440,560 \mathrm{~nm}$ and 610 $\mathrm{nm}$, respectively. These IPCE peaks are in accordance with the respective B-band and Q-bands in the absorption spectrum of Zn-5 in the solution shown in Fig. 1. It can be implied from the IPCE spectrum that the ratios of the peaks of the low-energy photon absorption to the peak of the high-energy photon absorption appeared to be 0.72 and 0.63 at the respective wavelengths of 570 and $610 \mathrm{~nm}$. These values are almost two times higher than those obtained from the IPCE data of ZnTPPCOOH (approximately 0.3 and 0.2 ). ${ }^{18}$ This suggested a substantial enhancement in the light harvesting efficiency in the visible region of $\mathbf{Z n - 5}$ absorbed on the $\mathrm{TiO}_{2}$ surface as a result of the $\mathrm{C}_{24}$-containing amide groups on the meso-phenyl substituents of the porphyrin macrocycle.

The $J-V$ curves of the devices with the volatile electrolyte under standard light illumination (AM 1.5G $100 \mathrm{~mW} \mathrm{~cm}^{-2}$ ) are shown in Fig. 5. The best Zn-5-based DSSC exhibited photovoltaic parameters; i.e. short-circuit photocurrent density $\left(J_{\mathrm{sc}}\right)$, an open-circuit voltage $\left(V_{\mathrm{oc}}\right)$ and a fill factor $(\mathrm{FF})$ of $5.6 \mathrm{~mA} \mathrm{~cm}{ }^{-2}$, $0.7 \mathrm{~V}$ and 0.78 , respectively, which yielded a photoconversion efficiency (PCE) of $3.1 \%$. To our surprise, the $J_{\mathrm{sc}}$ of the device increased up to $180 \%$ of the original value by simply exposing the device under the simulated full sunlight for 40 minutes before the $J-V$ measurement, leading to the incremental increase of the PCE value from $1.6 \%$ to $3.1 \%$. We assume that the steric effect of the porphyrin bearing the $\mathrm{C}_{24}$-containing amide groups can be subdued by the light exposure, allowing more photoelectrons to be generated and raising a passage of electrons throughout the redox mediator. On the other hand, by comparing with the results observed from ZnTPP-COOH that were reported earlier, ${ }^{18}$ it was found that the presence of the $\mathrm{C}_{24^{-}}$ containing amide groups at para positions of the meso-phenyl substituents of Zn-5 caused a remarkable increase in the photocurrent ( 4.2 vs. $5.6 \mathrm{~mA} \mathrm{~cm}^{-2}$ ). This phenomenon can be attributed to the long alkyl moieties enfolding in the circumference of the porphyrin macrocycles which decelerate the rate of the charge recombination between the photo-injected electron and $\mathrm{I}_{3}{ }^{-}$ions in the electrolyte at the $\mathrm{TiO}_{2} /$ electrolyte interface, corresponding to the previous studies. ${ }^{3}$ Nevertheless, the measured PCEs of the $\mathbf{Z n - 5}$-based devices are relatively low. This might be from the low amount of surface coverage of the dye molecules on $\mathrm{TiO}_{2}$ film due to the bulkiness of the long alkyl groups and the porphyrin aggregation on the $\mathrm{TiO}_{2}$ surface that was also found in the preceding reports. ${ }^{3,5,18}$

In order to elucidate the rate of electron recombination between $\mathbf{~ Z n - 5}, \mathrm{TiO}_{2}$ nanoparticles and the oxidized electrolyte, the transient photovoltage decay measurement was performed. Fig. 6a shows the electron recombination lifetime, which is the inverse of the recombination rate of the injected electrons, as a function of $V_{\mathrm{oc}}$ in the device. This data represents the difference between the redox level of the electrolyte and the quasi-Fermi level in the $\mathrm{TiO}_{2} \cdot{ }^{19}$ It appears in this plot that the electron lifetime decays exponentially with the stronger light intensity, suggesting that the recombination processes of the photoelectrons occur faster via the $\mathrm{I}_{3}{ }^{-}$ions in the electrolyte, compared with the recombination processes via the $\mathrm{TiO}_{2}$ phase, when the photoelectrons are filled in the higher energy states of $\mathrm{TiO}_{2}$. In addition, Fig. 6b shows the chemical capacitance-voltage characteristics of the device. The chemical capacitance is a representation of the electron density of state that increases with a bias potential at open circuit conditions as the density of state occupancy progresses. It is implied from Fig. $6 \mathrm{~b}$ that the chemical capacitance dependence on $V_{\mathrm{oc}}$ exhibits an approximate exponential form.

\section{Conclusions}

This study has shown that the synthesis of the target porphyrin bearing three $\mathrm{C}_{24}$-containing amide groups and a carboxyl group on meso-phenyl substituents was achieved. The presence of the $\mathrm{C}_{24}$-containing amide groups did not significantly affect the photophysical properties of the porphyrin dye. Cyclic voltammetry measurements gave a good understanding of the electrochemical behaviour of the dye and also indicated that the HOMO-LUMO energy levels of the dye were suitable for DSSC application. The device studies indicated that the presence of the $\mathrm{C}_{24}$-containing amide groups led to significant improvement of the DSSCs in terms of more efficient light harvesting in the Q-bands region and a higher photocurrent, compared to the previously reported ZnTPP-COOH-based DSSCs.

\section{Acknowledgements}

This research was supported by the National Research University Project of Thailand, Office of the Higher Education Commission (Project No. WCU-035-EN-57), and Graduate School of Chulalongkorn University (The $90^{\text {th }}$ Anniversary of Chulalongkorn University Fund, Ratchadaphiseksomphot 
Endowment Fund). The device fabrications and the photovoltaic measurements were performed at École Polytechnique Fédérale de Lausanne (EPFL), Switzerland.

\section{References}

1 Selected publications: (a) K. Kalyanasundaram, N. Vlachopoulos, V. Krishnan, A. Monnier and M. Grätzel, J. Phys. Chem., 1987, 91, 2342; (b) A. Kay and M. Grätzel, J. Phys. Chem., 1993, 97, 6272; (c) D. Wohrle, B. Tennigkeit, J. Elbe, L. Kreienhoop and G. Schurpfeil, Mol. Cryst. Liq. Cryst., 1993, 230, 221; (d) S. Cherian and C. C. Wamser, J. Phys. Chem. B, 2000, 104, 3624; (e) F. Odobel, E. Blart, M. Lagree, M. Villieras, H. Boujtita, N. El Murr, S. Caramori and C. A. Bignozzi, J. Mater. Chem., 2003, 13, 502; (f) W. M. Campbell, A. K. Burrell, D. L. Officer and K. W. Jolly, Coord. Chem. Rev., 2004, 248, 1363; (g) H. Imahori, J. Phys. Chem. B, 2004, 108, 6130; $(h)$ T. Hasobe, S. Fukuzumi and P. V. Kamat, J. Phys. Chem. B, 2006, 110, 25477; (i) M. A. Baldo, D. F. O’Brien, Y. You, A. Shoustikov, S. Sibley, M. E. Thompson and S. R. Forrest, Nature, 1998, 395, 151; (j) R. C. Kwong, S. Sibley, T. Dubovoy, M. Baldo, S. R. Forrest and M. E. Thompson, Chem. Mater., 1999, 11, 3709; (k) T. F. Guo, S. C. Chang, Y. Yang, R. C. Kwong and W. E. Thompson, Org. Electrochem., 2000, 1, 15; $(l)$ E. M. Gross, N. R. Armstrong and R. M. Wightman, J. Electrochem. Soc., 2002, 149, E137; (m) V. A. Montes, C. Perez-Bolivar, N. Agarwal, J. Shinar and P. Anzenbacher, J. Am. Chem. Soc., 2006, 128, 12436; (n) X. Wang, H. Wang, Y. Yang, Y. He, L. Zhang, Y. Li and X. Li, Macromolecules, 2010, 43, 709; (o) Y. Y. Noh, K. Yase and S. Nagamatsu, Appl. Phys. Lett., 2003, 83, 1243; (p) P. Checcoli, G. Conte, S. Salvatori, R. Paolesse, A. Bolognesi, A. Berliocchi, F. Brunetti, A. D'Amico, A. Di Carlo and P. Lugli, Synth. Met., 2003, 138, 261; (q) P. B. Shea, J. Kanicki and N. Ono, J. Appl. Phys., 2005, 98, 014503; (r) C.-M. Che, H.-F. Xiang, S. S.-Y. Chui, Z.-X. Xu, V. A. L. Roy, J. J. Yan, W.-F. Fu, P. T. Lai and I. D. Williams, Chem.-Asian J., 2008, 3, 1092.

2 (a) A. Yella, H.-W. Lee, H. N. Tsao, C. Yi, A. K. Chandiran, M. K. Nazeeruddin, E. W.-G. Diau, S. M. Zakeeruddin and M. Grätzel, Science, 2011, 334, 629; (b) S. Mathew, A. Yella, P. Gao, R. Humphry-Baker, B. F. E. Curchod, N. AshariAstani, I. Tavernelli, U. Rothlisberger, M. K. Nazeeruddin and M. Grätzel, Nat. Chem., 2014, 6, 242.

3 (a) A. Forneli, M. Planells, M. A. Sarmentero, E. MartinezFerrero, B. C. O'Regan, P. Ballester and E. Palomares, J.
Mater. Chem., 2008, 18, 1652; (b) M. Planells, A. Forneli, E. Martinez-Ferrero, A. Sánchez-Díaz, M. A. Sarmentero, P. Ballester, E. Palomares and B. C. O'Regan, Appl. Phys. Lett., 2008, 92, 153506.

4 J. E. Kroeze, N. Hirata, S. Koops, M. K. Nazeeruddin, L. Schmidt-Mende, M. Grätzel and J. R. Durrant, J. Am. Chem. Soc., 2006, 128, 16376.

5 A. Islam, S. P. Singh, M. Yanagida, M. R. Karim and L. Han, Int. J. Photoenergy, 2011, 2011, 757421.

6 (a) Z. Xiao, K. Sun, J. Subbiah, S. Ji, D. J. Jones and W. W. H. Wong, Sci. Rep., 2014, 4, 5701; (b) T. Aytun, L. Barreda, A. Ruiz-Carretero, J. A. Lehrman and S. I. Stupp, Chem. Mater., 2015, 7, 1201.

7 A. D. Adler, F. R. Longo, J. D. Finarelli, J. Goldmacher, J. Assour and L. Korsakoff, J. Org. Chem., 1967, 32, 476.

8 N. M. Howarth, W. E. Lindsell, E. Murray and P. N. Preston, Tetrahedron, 2005, 61, 8875.

9 C. Reanprayoon, J. Gasiorowski, M. Sukwattanasinitt, N. S. Sariciftci and P. Thamyongkit, RSC Adv., 2014, 4, 3045. 10 J. Jiao, P. Thamyongkit, I. Schmidt, J. S. Lindsey and D. F. Bocian, J. Phys. Chem. C, 2007, 111, 12693.

11 V. V. Pavlishchuk and A. W. Addison, Inorg. Chim. Acta, 2000, 298, 97.

12 P. Wang, M. Zakeeruddin, P. Comte, R. Charvet, R. Humphry-Baker and M. J. Graetzel, J. Phys. Chem. B, 2003, 107, 14336.

13 B. C. O'Regan and F. Lenzmann, J. Phys. Chem. B, 2004, 108, 4342.

14 M. E. El-Khouly, J. B. Ryu, K.-Y. Kay, O. Ito and S. Fukuzumi, J. Phys. Chem. C, 2009, 113, 15444.

15 Selected publications: (a) J. L. Coolidge, Am. Math. Mon., 1951, 58, 449; (b) P. R. Wolfson, Am. Math. Mon., 2001, 108, 206; (c) J. Stewart, Single Variable Calculus, Brooks/Cole Cengage Learning, USA, 7th edn, 2008.

16 A. J. Bard and L. R. Faulkner, Electrochemical Methods: Fundamentals and Applications, Wiley, New York, 2nd edn, 2000.

17 (a) S.-L. Wu, H.-P. Lu, H.-T. Yu, S.-H. Chuang, C.-L. Chiu, C.-W. Lee, E. W.-G. Diau and C.-Y. Yeh, Energy Environ. Sci., 2010, 3, 949; (b) A. Luechai, N. Pootrakulchote, T. Kengthanomma, P. Vanalabhpatana and P. Thamyongkit, J. Organomet. Chem., 2014, 753, 27.

18 H. He, A. Gurung and L. Si, Chem. Commun., 2012, 48, 5910. 19 J. Bisquert and V. S. Vikhrenko, J. Phys. Chem. B, 2004, 108, 2313. 